\title{
PHOTOPERIOD INFLUENCE ON THE BIOLOGY AND PHENOLOGICAL CHARACTERISTICS OF Dichelops melacanthus (DALLAS, 1851) (HETEROPTERA: PENTATOMIDAE)
}

\author{
CHOCOROSQUI, V. R. ${ }^{1}$ and PANIZZI, A. R. ${ }^{2}$ \\ ${ }^{1}$ Departamento de Zoologia, Universidade Federal do Paraná, C.P. 19020, Curitiba, Paraná, Brazil \\ ${ }^{2}$ Embrapa Labex, NCAUR/ARS/USDA, Peoria, IL 61604, USA \\ Correspondence to: Antônio R. Panizzi, Embrapa-Labex, NCAUR/ARS/USDA, Peoria, IL 61604, USA, \\ e-mail: panizzia@ncaur.usda.gov \\ Received August 27, 2002 - Accepted November 22, 2002 - Distributed November 30, 2003
}

(With 6 figures)

\begin{abstract}
The influence of the photoperiod on the biology and seasonal morphs of Dichelops melacanthus (Dallas, 1851 ) was studied in the laboratory. Four different photoperiods $(11,12,13$, and $14 \mathrm{hL}=$ hours of light) were tested, keeping the temperature at $25 \pm 1^{\circ} \mathrm{C}$ and the relative humidity at $65 \pm 5 \%$. Nymph developmental time tended to be longer under shorter photophases (11 and $12 \mathrm{hL}$ ). The 14-hour photophase (long day) resulted in lower nymph mortality rates. Females maintained at 13 and $14 \mathrm{hL}$ showed greater weight gain $\left(1^{\text {st }}-28^{\text {th }}\right.$ day) than females under $12 \mathrm{hL}$. D. melacanthus showed reproductive oligopause induced by short photophases, especially when exposed to $11 \mathrm{hL}$. Under 13 and $14 \mathrm{hL}, 85 \%$ and $65 \%$ of females oviposited, respectively, in comparison to $10 \%$ and $15 \%$ of females ovipositing under 11 and $12 \mathrm{hL}$, respectively. Fecundity (number of egg masses and number of eggs/female) was greater in the longer than under the shorter photophases. Seasonal dimorphism induced by photoperiod was observed in D. melacanthus adults. Under short-day conditions ( 11 and $12 \mathrm{hL}$ ), adults showed short and rounded shoulder spines, grayish brown abdomen (mainly in $11 \mathrm{hL}$ ), high lipid contents, and lower percentage of mature reproductive organs. Under long-day conditions (13 and $14 \mathrm{hL}$ ), the stink bugs showed greatly developed shoulder spines, green abdomen, low lipid contents, and mature reproductive organs.
\end{abstract}

Key words: diapause, development, reproductive performance, dimorphism, photophase.

\section{RESUMO}

Influência do fotoperíodo na biologia e nas características fenológicas de Dichelops melacanthus (Dallas, 1851) (Heteroptera: Pentatomidae)

A influência do fotoperíodo na biologia e nas formas sazonais de Dichelops melacanthus (Dallas, 1851) foi estudada em laboratório. Foram utilizadas quatro condições fotoperiódicas diferentes $(11,12,13$ e $14 \mathrm{hL}=$ horas de luz), mantendo a temperatura a $25 \pm 1^{\circ} \mathrm{C}$ e a umidade relativa a $65 \pm 5 \%$. O tempo de desenvolvimento das ninfas tendeu a ser mais longo nas fotofases mais curtas (11 e $12 \mathrm{hL}$ ). A fotofase de 14 horas (dia longo) foi a melhor condição para o desenvolvimento ninfal, apresentando baixos índices de mortalidade durante esse período. Fêmeas mantidas sob 13 e $14 \mathrm{hL}$ apresentaram maior ganho de peso ( $1^{\circ}-28^{\circ}$ dia) do que fêmeas sob $12 \mathrm{hL}$. D. melacanthus apresentou oligopausa reprodutiva induzida por fotofases curtas, principalmente sob $11 \mathrm{hL}$. Em 13 e $14 \mathrm{hL}, 85 \%$ e $65 \%$ de fêmeas ovipositaram, respectivamente, em comparação a 10\% e 15\% de fêmeas que ovipositaram sob 11 e $12 \mathrm{hL}$, respectivamente. A fecundidade (número de massas de ovos e número de ovos/fêmea) foi maior nas fotofases longas do que nas curtas. O dimorfismo sazonal induzido pelo fotoperíodo foi observado em adultos de D. melacanthus. Em condições de dias curtos (11 e $12 \mathrm{hL})$, os adultos apresentaram 
espinhos pronotais curtos e arredondados, abdômen marrom-acinzentado (principalmente em $11 \mathrm{hL}$ ), teor lipídico alto e baixa porcentagem de órgãos reprodutivos maduros. Sob condições de dias longos (13 e $14 \mathrm{hL}$ ), os percevejos apresentaram espinhos pronotais mais desenvolvidos e pontiagudos, abdômen verde, teor lipídico baixo e órgãos reprodutivos desenvolvidos.

Palavras-chave: diapausa, desenvolvimento, desempenho reprodutivo, dimorfismo, fotofase.

\section{INTRODUCTION}

The photoperiod is an abiotic factor that influences insect biology and behavior, and can be considered the main factor regulating diapause (Ali \& Ewiess, 1977). Diapause is the reduction or pause of insect metabolic activities during an unfavorable period and involves physiological, epidemical, biochemical, and behavioral changes (Leather et al., 1993).

Studies that associate photoperiod and diapause have been conducted with several species of pentatomids. Albuquerque (1993) observed in the laboratory that Oebalus poecilus (Dallas) is induced to diapause by short days. Adults of Aelia fieberi (Scott) are induced to diapause under short photoperiods, and long days promote reproduction (Nakamura \& Numata, 1997). Mourão \& Panizzi (2002) observed that Euschistus heros (Fabr.) presents reproductive diapause, which is induced by a 12-hour (or less) photophase. Usually, diapausant insects have immature reproductive organs and high lipid contents, associated with a feeding pause (Kiritani, 1963).

Another dormancy type, the oligopause, is common among insects living in climates with moderate winters. Insects in oligopause periodically feed during the dormancy period, even with lipid accumulation during the preparatory period (Leather et al., 1993).

According to McPherson (1974), photoperiod causes phenological changes in pentatomids, such as different seasonal morphs. For example, E. heros showed short and rounded shoulder spines when maintained under short photophases during nymphal stage (Mourão \& Panizzi, 2002).

Stink bugs of the genus Dichelops (Diceraeus) are important soybean pests and have recently been associated with corn and wheat, causing heavy damage to young plants cultivated under the notillage system (Panizzi \& Chocorosqui, 2000). These bugs, which were collected in southern Brazil during a one-year period, showed different seasonal morphs (Chocorosqui \& Panizzi, unpublished). In Rio Grande do Sul State, this pentatomid shows behavior similar to that of E. heros during autumn and winter. The insects were inactive, usually sheltered under crop residues, with abdomens turned upward. The abiotic and biotic factors involved in insect seasonality need to be understood in order to develop better control methods for integrated pest management programs.

This study was carried out to evaluate photoperiod influence on nymph development, and also on adult longevity, weight gain, reproductive performance, and phenological changes of Dichelops melacanthus (Dallas) in the laboratory.

\section{MATERIAL AND METHODS}

\section{Nymph biology}

Adults of D. melacanthus were collected in 1999 at the Embrapa Soybean Farm, in Londrina, PR (latitude $23^{\circ} 55^{\prime} 46^{\prime \prime} \mathrm{S}$ ) and placed in a gerbox $(11.0 \times 11.0 \times 3.5 \mathrm{~cm})$ to obtain eggs. They were fed green pods and dry soybean seeds [Glycine max (L.) Merrill] variety 'Paraná', and maintained at $25 \pm 1{ }^{\circ} \mathrm{C}, 65 \pm 5 \% \mathrm{RH}$, and 14-hour photophase. Egg masses were mixed to avoid a genetic effect. Eggs were conditioned in Petri dishes $(9.0 \times 1.5 \mathrm{~cm})$ lined with moistened filter paper and maintained in four different photophases: 11 hours of light $(11 \mathrm{hL})$, $12 \mathrm{hL}, 13 \mathrm{hL}$, and $14 \mathrm{hL}$. Temperature and relative humidity were kept constant $\left(25 \pm 1^{\circ} \mathrm{C}\right.$ and $65 \pm$ $5 \%$, respectively).

During the 1st instar, nymphs were maintained only with distilled water. On the first day of the 2 nd instar, 30 nymphs from each photophase were individualized in Petri dishes $(9.0 \times 1.5 \mathrm{~cm})$ lined with filter paper. They were fed with green pods and dry soybean seeds, and supplied daily with distilled water. The same photoperiod used for the egg stage was maintained throughout nymphal development. Instar changes and mortality were observed daily.

Upon emergence, adults were separated by sex and weight on an electronic scale (Mettler Toledo PB 303). Instar duration, developmental time, and nymph mortality were calculated for nymphs under 
each photoperiod. Treatments were set up in a completely randomized design, with the number of nymphs $(n=30)$ considered replicates. Data were submitted to analysis of variance, and means compared using Tukey's test $(\mathrm{p} \leq 0.05)$.

\section{Adult biology}

Egg masses were obtained as described above. Eggs from different egg masses were mixed and divided into four groups, which were conditioned in Petri dishes $(9.0 \times 1.5 \mathrm{~cm})$ lined with moistened filter paper, and maintained under four different photophases: $11 \mathrm{hL}, 12 \mathrm{hL}, 13 \mathrm{hL}$, and $14 \mathrm{hL}$. Temperature and relative humidity were kept constant (25 $\pm 1^{\circ} \mathrm{C}$ and $65 \pm 5 \%$, respectively).

Groups of ten 2 nd instar nymphs were placed in a gerbox $(11.0 \times 11.0 \times 3.5 \mathrm{~cm})$ lined with filter paper and fed with green pods and dry soybean seeds. Nymphs were reared under the same photoperiod as that of the egg stage. Food was renewed every other day and humidity was maintained by using moistened cotton in a plastic container $(3.0 \mathrm{~cm}$ diameter). At adult emergence, 20 couples were formed for each photoperiod. Each couple was conditioned in a gerbox and fed with the same food offered to the nymphs. They were supplied daily with distilled water and food was renewed every other day.

Fresh body weights of females and males were taken on the $1 \mathrm{st}, 7^{\text {th }}, 14^{\text {th }}, 21^{\text {st }}$, and $28^{\text {th }}$ days of adult life. The weight gain between two evaluations was calculated by subtracting the last weighing from the previous one. The total weight gain was obtained by subtracting the weight on day 28 from the weight on day 1 . The insects were observed periodically to verify feeding occurrence in each photoperiod. The reproductive activity was evaluated through the following parameters: percentage of ovipositing females, preoviposition period, number of egg masses/ female, number of eggs/female, and egg viability.

Longevity and survival of males and females were also evaluated in the several photophases. Treatments were set up in a completely randomized design, and the number of couples $(n=20)$ considered replicates. Data were submitted to analysis of variance, and means were compared using Tukey's test $(\mathrm{p} \leq 0.05)$.

\section{Seasonal morphs and lipid contents}

Egg masses of D. melacanthus obtained in the laboratory were mixed to eliminate the genetic effect. Four groups of eggs $(n=50)$ were conditioned under different photophases: $11 \mathrm{hL}, 12 \mathrm{hL}, 13 \mathrm{hL}$, and $14 \mathrm{hL}$, with constant temperature and relative humidity $(25 \pm$ $1^{\circ} \mathrm{C}$ and $65 \pm 5 \%$, respectively). Nymphs were conditioned and fed in the same way as nymphs reared for adult biology. Abdomen coloration of oneday-old adults $(n=20)$ was evaluated.

Adults were maintained, under the same conditions described above, for 20 days, time enough to reach sexual maturity under ideal conditions. After that, adults were killed by freezing to evaluate the following parameters: right shoulder spine length, shoulder spine shape (short, long, rounded, or pointed) and abdomen coloration. The shape of the shoulder spine was evaluated based only on its morphological aspect. Afterwards, the adults were divided into two groups $(\mathrm{n}=10$ each). In the first one, lipid content was measured using the following method: 1 . insects were taken to the oven $\left(60^{\circ} \mathrm{C}\right)$ for about 48 hours; 2 . dry weight (DW) was obtained using an electronic scale (Mettler Toledo PB 303); 3 . insects were identified with a number and individualized in cloth packages $(3.0 \times 4.0 \mathrm{~cm}) ; 4$. packages were conditioned in extraction tubes $(7.5 \mathrm{x}$ $3.0 \mathrm{~cm}) ; 5.250 \mathrm{ml}$ of the extraction solvent (hexane) was added to a volumetric balloon and placed in the Soxhlet extractor, with circulation water and tubes; 6. equipment was heated up to ca. $120^{\circ} \mathrm{C}$. After the first cycle, the extraction process was maintained for three hours; 7. adults were placed again in the oven $\left(60^{\circ} \mathrm{C}\right)$ for 24 hours; 8 . weight without lipid ("thin weight" = TW) was obtained, and the following formula was applied to obtain percentage $(\%)$ of stored lipid:

$$
\% \text { Lipid }=(\mathrm{DW}-\mathrm{TW}) \times 100 / \mathrm{DW}
$$

The second group of adults was dissected and the reproductive organs developmental stage evaluated. Alcohol (70\%) was used for cleaning the abdominal cavity of the insects to allow the best view of the reproductive organs, which were classified as immature or mature. Mature females presented distended ovaries, usually filled with green eggs. Immature females presented small and empty ovaries, without any differentiation or development. Mature males were charaterized by developed testicles occupying most of the abdominal cavity. Immature males showed normal testicles, but smaller than developed testicles. The portion of the abdominal cavity occupied by the testicles was smaller than in mature males. 
Treatments were set up in a completely randomized design, with replicates (n) as stated above. Data were submitted to analysis of variance, and means compared using Tukey's test $(\mathrm{p} \leq 0.05)$.

\section{RESULTS AND DISCUSSION}

\section{Nymph biology}

Photoperiod influenced mortality of $D$. melacanthus nymphs. During the $2^{\text {nd }}$ instar, mortality tended to be greater at $11 \mathrm{hL}(46.7 \%)$ (Fig. 1). However, it dropped during the $3^{\text {rd }}$ instar, and no nymphs died during the $4^{\text {th }}$ and $5^{\text {th }}$ instars under $11 \mathrm{hL}$. Total nymph mortality (instars 2-5) in this photophase was $53.4 \%$. In the other photophases, nymph mortality ranged from $10.0(12$ and $13 \mathrm{hL})$ to $16.7 \%(14 \mathrm{hL})$ during the $2^{\text {nd }}$ instar. Nymphs reared under $12 \mathrm{hL}$ showed greater mortality during the $5^{\text {th }}$ instar, reaching $43.4 \%$. Under $13 \mathrm{hL}$, mortality was $30.0 \%$ and $50.0 \%$ during the $3^{\text {rd }}$ and $4^{\text {th }}$ instar, respectively. Total nymph mortality was the same as for $11 \mathrm{hL}$ of photophase $(53.4 \%)$. Under $14 \mathrm{hL}$, only $30.0 \%$ of $D$. melacanthus nymphs did not complete development. Mourão \& Panizzi (2000b) working with another species of pentatomid, E. heros, also observed greater mortality of those under short photoperiod (56.7\%), in comparison to nymphs under $14 \mathrm{hL}(28.3 \%)$.

Nymphs tended to complete development faster under longer photoperiods. The $2^{\text {nd }}$ instar lasted longer at 11,12 , and $13 \mathrm{hL}$, in comparison to $14 \mathrm{hL}$ (Table 1). In the $3^{\text {rd }}$ instar, nymphs tended to develop faster at $14 \mathrm{hL}$. During the $4^{\text {th }}$ and $5^{\text {th }}$ stadia, the developmental time was longer at $12 \mathrm{hL}$ than at 13 and $14 \mathrm{hL}$. There was also a significant difference in $5^{\text {th }}$ instar duration between nymphs reared at $14 \mathrm{hL}$ (5.9 days) and $11 \mathrm{hL}$ (8.6 days).

For males, total developmental time (instars 2-5) was shorter under $14 \mathrm{hL}$, in comparison to the other photoperiods. For females, there was a significant difference only between $14 \mathrm{hL}$ (17.4 days) and the shortest photophases (11 and $12 \mathrm{hL})$. These results are supported by Mourão \& Panizzi (2000b), who reported longer developmental time for E. heros nymphs under short photoperiod $(10 \mathrm{hL})$, than that under $14 \mathrm{hL}$. The fresh body weight of males and females of $D$. melacanthus did not differ statistically among treatments.

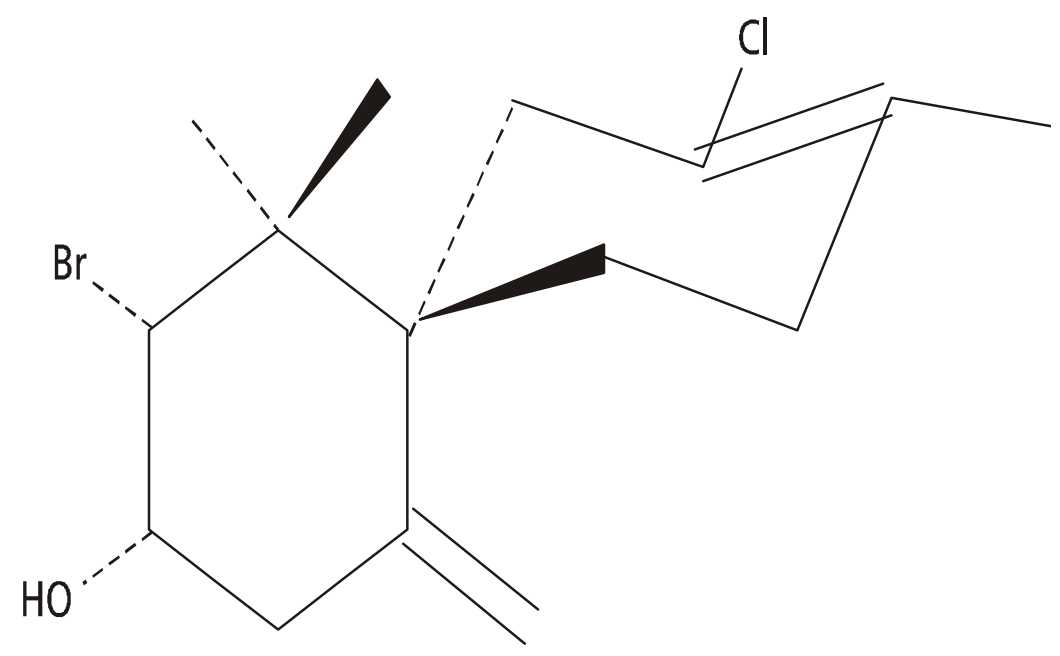

Fig. 1 - Mortality (\%) of Dichelops melacanthus nymphs reared under different photoperiods, feeding on green pods and dry soybean seeds in the laboratory $(n=30)$. 
TABLE 1

Mean \pm SEM development time and fresh body weight of Dichelops melacanthus maintained under different photoperiods, and fed with green pods and dry soybean seeds (number of nymphs in parentheses).

\begin{tabular}{|c|c|c|c|c|c|c|c|c|}
\hline \multirow{3}{*}{$\begin{array}{c}\text { Photophase } \\
\text { (hours) }\end{array}$} & \multicolumn{6}{|c|}{ Development time $^{1}$} & \multicolumn{2}{|c|}{ Fresh body weight ${ }^{1}$} \\
\hline & \multirow{2}{*}{$2^{\text {nd }}$ instar } & \multirow{2}{*}{$3^{\text {rd }}$ instar } & \multirow{2}{*}{$4^{\text {th }}$ instar } & \multirow{2}{*}{$5^{\text {th }}$ instar } & \multicolumn{2}{|c|}{$2^{\text {nd }}-5^{\text {th }}$ instar } & \multirow{2}{*}{ Female } & \multirow{2}{*}{ Male } \\
\hline & & & & & Female & Male & & \\
\hline 11 & $\begin{array}{c}6.2 \pm 0.54 \mathrm{a} \\
(16)\end{array}$ & $\begin{array}{c}4.6 \pm 0.29 \mathrm{a} \\
\text { (14) }\end{array}$ & $\begin{array}{c}5.5 \pm 0.29 \mathrm{ab} \\
(14)\end{array}$ & $\begin{array}{c}8.6 \pm 0.84 \mathrm{ab} \\
(14)\end{array}$ & $\begin{array}{c}25.5 \pm 1.65 \mathrm{a} \\
(6)\end{array}$ & $\begin{array}{c}24.0 \pm 0.33 \mathrm{a} \\
(8)\end{array}$ & $\begin{array}{c}47.0 \pm 2.17 \mathrm{a} \\
\text { (6) }\end{array}$ & $\begin{array}{c}47.0 \pm 2.53 \mathrm{a} \\
\text { (8) }\end{array}$ \\
\hline 12 & $\begin{array}{c}5.4 \pm 0.27 \mathrm{a} \\
(27)\end{array}$ & $\begin{array}{c}5.5 \pm 0.50 \mathrm{a} \\
(25)\end{array}$ & $\begin{array}{c}7.7 \pm 1.00 \mathrm{a} \\
(23)\end{array}$ & $\begin{array}{c}9.8 \pm 0.81 \mathrm{a} \\
(17)\end{array}$ & $\begin{array}{c}27.2 \pm 2.40 \mathrm{a} \\
\text { (9) }\end{array}$ & $\begin{array}{c}26.4 \pm 2.63 \mathrm{a} \\
(8)\end{array}$ & $\begin{array}{c}52.4 \pm 2.65 \mathrm{a} \\
(9)\end{array}$ & $\begin{array}{c}46.0 \pm 1.72 \mathrm{a} \\
(8)\end{array}$ \\
\hline 13 & $\begin{array}{c}5.4 \pm 0.36 \mathrm{a} \\
(27)\end{array}$ & $\begin{array}{c}5.1 \pm 0.64 \mathrm{a} \\
(21)\end{array}$ & $\begin{array}{c}4.3 \pm 0.33 b \\
(15)\end{array}$ & $\begin{array}{c}7.1 \pm 0.19 b c \\
\text { (14) }\end{array}$ & $\begin{array}{c}21.7 \pm 1.14 \mathrm{ab} \\
(11)\end{array}$ & $\begin{array}{c}26.0 \pm 3.46 \mathrm{a} \\
(3)\end{array}$ & $\begin{array}{c}51.3 \pm 1.57 \mathrm{a} \\
\text { (11) }\end{array}$ & $\begin{array}{c}42.7 \pm 3.48 \mathrm{a} \\
\text { (3) }\end{array}$ \\
\hline 14 & $\begin{array}{c}4.1 \pm 0.08 \mathrm{~b} \\
(25)\end{array}$ & $\begin{array}{c}3.9 \pm 0.19 \mathrm{a} \\
(22)\end{array}$ & $\begin{array}{c}4.1 \pm 0.38 \mathrm{~b} \\
(21)\end{array}$ & $\begin{array}{c}5.9 \pm 0.19 \mathrm{c} \\
(21)\end{array}$ & $\begin{array}{c}17.4 \pm 1.02 \mathrm{~b} \\
(8)\end{array}$ & $\begin{array}{c}18.2 \pm 0.63 \mathrm{~b} \\
(13)\end{array}$ & $\begin{array}{c}53.1 \pm 2.17 \mathrm{a} \\
(8)\end{array}$ & $\begin{array}{c}48.6 \pm 1.97 \mathrm{a} \\
(13)\end{array}$ \\
\hline
\end{tabular}

${ }^{1}$ Means followed by the same letter in each column do not differ significantly using Tukey's test $(\mathrm{p} \leq 0.05)$.

\section{Adult biology}

Weight gain of males and females of $D$. melacanthus occurred mostly during the first days of adult life, up to day 14 (Fig. 2). In spite of the tendency to greater weight gain under 13 and $14 \mathrm{hL}$ until day 7 , there was no significant difference in weight gain/week among all the photophases, during the 4-week evaluation period. A significant difference was detected in the total weight gain of females (days 1-28). Females maintained in 13 and $14 \mathrm{hL}$ (summer photophases in southern Brazil) showed greater weight gain than females at $12 \mathrm{hL}$. In the former photophases, nutrient intake may have been greater. However, this tendency to greater food intake in longer photophases did not occur with females at $11 \mathrm{hL}$, which gained weight similary to those under 13 and $14 \mathrm{hL}$. Obviously, further studies are needed to clarify this point. Adults in all photophases were observed to feed continuously, showing that this activity was not affected by reduced photoperiod.

Reproductive performance of females also varied with the different photoperiods tested (Table 2): $85 \%$ and $65 \%$ of the females oviposited at 13 and $14 \mathrm{hL}$, respectively, but under 11 and $12 \mathrm{hL}$, only $10 \%$ and $15 \%$ of females oviposited, respectively. Preoviposition period was longer for females maintained under 11 and $12 \mathrm{hL}$, in comparison to females at $14 \mathrm{hL}$. For females under 13 and $14 \mathrm{hL}$, fecundity (number of egg masses and number of eggs) was greater than that of females under 11 and $12 \mathrm{hL}$ (local winter photophases); egg hatchability, however, only tended to be higher in longer photophases. Mourão \& Panizzi (2002) reported that female E. heros kept under 14
$\mathrm{hL}$ showed better reproductive performance, in comparison to females under $12 \mathrm{hL}$, which did not oviposit, and in $10 \mathrm{hL}$, which produced unfertile eggs. For the pentatomid Nezara viridula L., Ali \& Ewiess (1977) observed no differences in reproductive performance under either $10 \mathrm{hL}$ (short photophase) or $14 \mathrm{hL}$ (long photophase). However, there were significant differences in fecundity and preoviposition period for Dolycoris baccarum L. under long-day (266 eggs and 38 days, respectively) and short-day conditions (95 eggs and 54 days, respectively) (Hodek \& Hodková, 1993).

\section{Seasonal morphs and lipid contents}

Shoulder spine length of D. melacanthus was statistically different among treatments. Males maintained under $14 \mathrm{hL}$ presented more pointed and longer shoulder spines than males under 11 and $12 \mathrm{hL}$ (Table 3, Fig. 3). Males at $13 \mathrm{hL}$ also presented longer and sharper shoulder spines, but the spine length did not differ from that under the other treatments. Females under summer photophases ( 13 and $14 \mathrm{hL}$ ) presented pointed and longer shoulder spines compared to females under winter photophases (11 and $12 \mathrm{hL}$ ). The latter, as well as the males, had rounded and shorter shoulder spines.

The photoperiod influence on the shoulder spine shape and length has been reported for $O$. poecilus (Albuquerque, 1989) and E. heros (Mourão \& Panizzi, 2002). According to McPherson (1975), the shoulder spine length and body coloration are the most relevant aspects of seasonal dimorphism controlled by the photoperiod in pentatomids. 


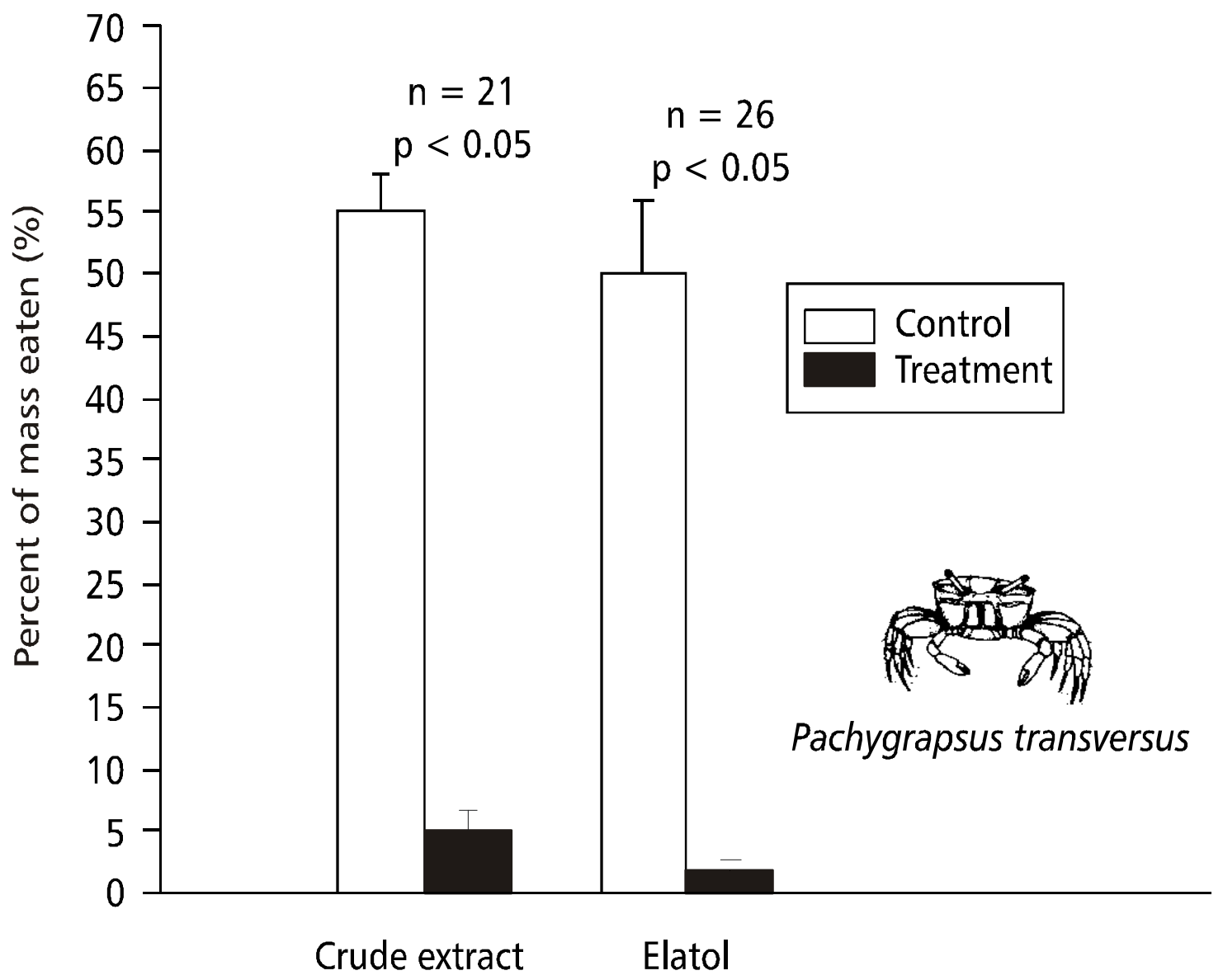

Fig. 2 - Weight gain $(\mathrm{mg})(\mathrm{X} \pm \mathrm{SEM})$ of Dichelops melacanthus adults maintained under different photoperiods, and fed with green pods and dry soybean seeds in the laboratory (evaluated weekly, from the $1^{\text {st }}$ to the $28^{\text {th }}$ day of adult life). Means followed by the same letter, among individuals of the same sex, do not differ significantly (Tukey's test, $\mathrm{p} \leq 0.05 ; \mathrm{n}=20$ ).

TABLE 2

Reproductive performance of Dichelops melacanthus under different photoperiods, feeding on green pods and dry soybean seed in the laboratory (number of females in parentheses).

\begin{tabular}{|c|c|c|c|c|c|}
\hline \multirow[b]{2}{*}{$\begin{array}{c}\text { Photophase } \\
\text { (hours) }\end{array}$} & \multirow[b]{2}{*}{$\begin{array}{c}\text { Females ovipositing } \\
(\%)\end{array}$} & \multirow{2}{*}{$\begin{array}{c}\text { Preoviposition } \\
\text { period (days) } \\
(X \pm S E M)^{2}\end{array}$} & \multicolumn{2}{|c|}{ Number/female $^{1}$} & \multirow[b]{2}{*}{$\begin{array}{l}\text { Egg hatchability }(\%) \\
(X \pm S E M)\end{array}$} \\
\hline & & & $\begin{array}{c}\text { Egg masses } \\
(\mathrm{X} \pm \mathrm{SEM})\end{array}$ & $\begin{array}{c}\text { Eggs } \\
(\mathrm{X} \pm \mathrm{SEM})\end{array}$ & \\
\hline 11 & $\begin{array}{l}10 \\
(2)\end{array}$ & $29.0 \pm 2.00 \mathrm{a}$ & $1.5 \pm 0.50 b$ & $14.5 \pm 6.50 b$ & $17.5 \pm 12.65 \mathrm{a}$ \\
\hline 12 & $\begin{array}{l}15 \\
(3) \\
\end{array}$ & $23.3 \pm 5.36 \mathrm{ab}$ & $3.6 \pm 1.45 \mathrm{ab}$ & $25.3 \pm 6.33 \mathrm{ab}$ & $45.2 \pm 45.25 \mathrm{a}$ \\
\hline 13 & $\begin{array}{c}85 \\
(17) \\
\end{array}$ & $17.3 \pm 1.59 \mathrm{bc}$ & $6.2 \pm 1.23 \mathrm{ab}$ & $47.7 \pm 12.74 \mathrm{a}$ & $64.7 \pm 9.11 \mathrm{a}$ \\
\hline 14 & $\begin{array}{c}65 \\
(13)\end{array}$ & $12.4 \pm 0.73 \mathrm{c}$ & $7.9 \pm 2.68 \mathrm{a}$ & $55.8 \pm 13.83 \mathrm{a}$ & $55.5 \pm 13.00 \mathrm{a}$ \\
\hline
\end{tabular}

${ }^{1}$ Data on female ovipositing.

${ }^{2}$ Means followed by the same letter in each column do not differ significantly using Tukey's test $(\mathrm{P} \leq 0.05)$. 

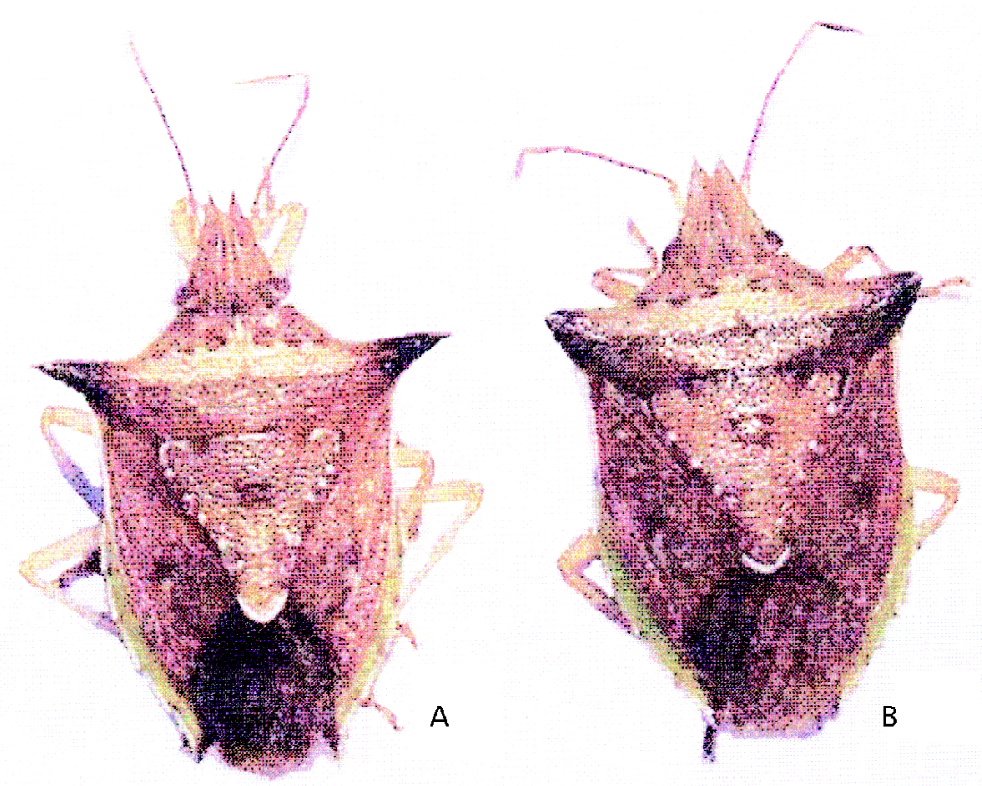

Fig. 3 - Shoulder spine morphs of Dichelops melacanthus observed under 13 and $14 \mathrm{hL}$ (A) and 11 and $12 \mathrm{hL}$ (B) of photophase.

TABLE 3

Phenological characteristics of Dichelops melacanthus adults maintained under different photoperiods, fed with green pods and dry soybean seeds in the laboratory (number of adults in parentheses).

\begin{tabular}{|c|c|c|c|c|c|c|c|c|c|c|c|c|c|c|}
\hline \multirow{4}{*}{$\begin{array}{c}\text { Photophase } \\
\text { (hours) }\end{array}$} & \multirow{3}{*}{\multicolumn{2}{|c|}{$\begin{array}{c}\text { Shoulder spine } \\
\text { length }(\mathbf{m m})^{1}\end{array}$}} & \multicolumn{4}{|c|}{ Shoulder spines $^{2}$} & \multicolumn{8}{|c|}{ Abdominal coloration } \\
\hline & & & \multirow{2}{*}{\multicolumn{2}{|c|}{ Male }} & \multirow{2}{*}{\multicolumn{2}{|c|}{ Female }} & \multicolumn{4}{|c|}{ Male } & \multicolumn{4}{|c|}{ Female } \\
\hline & & & & & & & \multicolumn{2}{|c|}{$1^{\text {st }}$ day } & \multicolumn{2}{|c|}{$20^{\text {th }}$ day } & \multicolumn{2}{|c|}{$1^{\text {st }}$ day } & \multicolumn{2}{|c|}{$20^{\text {th }}$ day } \\
\hline & $\begin{array}{c}\text { Male } \\
(\mathrm{X} \pm \mathrm{SEM})\end{array}$ & $\begin{array}{c}\text { Female } \\
(\mathbf{X} \pm \text { SEM }) \\
\end{array}$ & \begin{tabular}{|c|} 
Long \\
$(\%)$
\end{tabular} & $\begin{array}{c}\text { Short } \\
(\%)\end{array}$ & $\begin{array}{c}\text { Long } \\
(\%)\end{array}$ & $\begin{array}{c}\text { Short } \\
(\%)\end{array}$ & $\begin{array}{c}G^{3} \\
(\%)\end{array}$ & $\begin{array}{l}\text { GB } \\
(\%)\end{array}$ & $\begin{array}{c}G \\
(\%)\end{array}$ & $\begin{array}{l}\text { GB } \\
(\%)\end{array}$ & $\begin{array}{c}G \\
(\%) \\
\end{array}$ & $\begin{array}{l}\text { GB } \\
(\%)\end{array}$ & $\begin{array}{c}G \\
(\%)\end{array}$ & $\begin{array}{l}\text { GB } \\
(\%) \\
\end{array}$ \\
\hline 11 & $\begin{array}{c}2.1 \pm 0.06 \mathrm{~b} \\
(20)\end{array}$ & $\begin{array}{c}2.2 \pm 0.03 \mathrm{~b} \\
(20)\end{array}$ & 0.0 & 100.0 & 0.0 & 100.0 & 44.4 & 65.6 & 25.0 & 75.0 & 70.0 & 30.0 & 10.0 & 90.0 \\
\hline 12 & $\begin{array}{c}2.1 \pm 0.05 \mathrm{~b} \\
(20)\end{array}$ & $\begin{array}{c}2.2 \pm 0.04 \mathrm{~b} \\
(20)\end{array}$ & 0.0 & 100.0 & 7.7 & 92.3 & 100.0 & 0.0 & 90.0 & 10.0 & 100.0 & 0.0 & 80.0 & 20.0 \\
\hline 13 & $\begin{array}{c}2.2 \pm 0.04 \mathrm{ab} \\
(20)\end{array}$ & $\begin{array}{c}2.3 \pm 0.05 \mathrm{a} \\
(20)\end{array}$ & 100.0 & 0.0 & 100.0 & 0.0 & 100.0 & 0.0 & 90.0 & 10.0 & 100.0 & 0.0 & 100.0 & 0.0 \\
\hline 14 & $\begin{array}{c}2.4 \pm 0.05 \mathrm{a} \\
(20)\end{array}$ & $\begin{array}{l}2.5 \pm 0.04 \mathrm{a} \\
(20)\end{array}$ & 100.0 & 0.0 & 100.0 & 0.0 & 100.0 & 0.0 & 100.0 & 0.0 & 100.0 & 0.0 & 100.0 & 0.0 \\
\hline
\end{tabular}

${ }^{1}$ Means followed by the same letter in each column do not differ significantly using Tukey's test ( $\left.\mathrm{p} \leq 0.05\right)$.

${ }^{2}$ Data based only on morphologic aspect.

${ }^{3} \mathrm{G}=$ green; $\mathrm{GB}=$ grayish browm.

Two distinct abdomenal colors, green and grayish brown, were observed. Under 12, 13, and $14 \mathrm{hL}, 100 \%$ of males and females showed green abdomens on the $1^{\text {st }}$ day of adult life (Fig. 4). On the $20^{\text {th }}$ day, green was the predominant color $(100 \%)$ for females kept under 13 and $14 \mathrm{hL}$, and males under $14 \mathrm{hL}$. Only $10 \%$ of males kept at $13 \mathrm{hL}$ changed their abdomenal color to grayish brown 
after 20 days. At $12 \mathrm{hL}, 10 \%$ of males and $20 \%$ of females changed abdomenal color from green to grayish brown after 20 days. Grayish brown was the predominant color of males maintained under $11 \mathrm{hL}$. On the $1^{\text {st }}$ day, only $30 \%$ of females under $11 \mathrm{hL}$ showed grayish brown abdomen. However, after 20 days, $90 \%$ of the females showed this coloration.

These results indicate that $D$. melacanthus abdomenal coloration is related to two factors: photoperiod and adult age. For field-collected insects, whose age cannot be estimated, abdomenal coloration is not a good parameter to indicate hibernation state or seasonal morph. Furthermore, body coloration was not considered a reliable parameter of the physiological state of E. heros (Mourão \& Panizzi, 2000a). A similar conclusion reached by Seymour \& Bowman (1994) working with the pentatomid $N$. viridula, contradicted that of Harris et al. (1984), who referred to body coloration (russet) as the easiest and fastest method to determine diapause and seasonal morph of this bug.
The lipid contents extracted from $D$. melacanthus adults were significantly higher when insects were maintained under short photophases (11 and $12 \mathrm{hL}$ ), in comparison to the $14 \mathrm{hL}$ one (Fig. 5). The lipid contents at $13 \mathrm{hL}$ did not differ from those found under the other treatments. These results agree with those of Kiritani (1963), who noted that insects in diapause show immature reproductive organs and great amounts of stored lipid. Immature reproductive organs were observed when insects were maintained under short photophases (Fig. 6). Under 13 and $14 \mathrm{hL}$, all insects presented mature testicles or ovaries. Under $12 \mathrm{hL}, 40 \%$ of males and $60 \%$ of females had immature reproductive organs. Under $11 \mathrm{hL}$, the percentage of immature organs was higher (89.9 and $81.8 \%$, for males and females, respectively) than under the other photophases, confirming the occurrence of reproductive oligopause (hibernation with periodic feeding) under this photoperiodic condition. Hibernation induction by short photophases was reported for other pentatomids (Higuchi, 1994; Nakamura et al., 1996; Mourão \& Panizzi, 2000a).

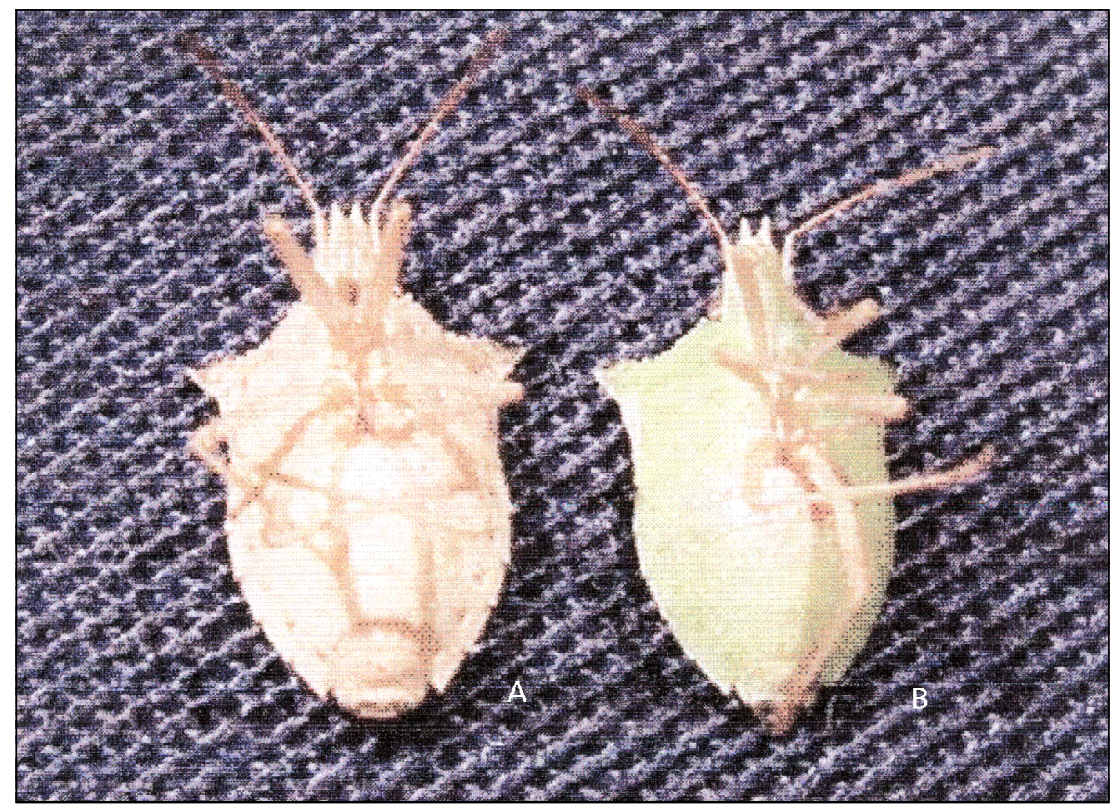

Fig. 4 - Abdominal coloration of Dichelops melacanthus: A = grayish-brown (adults kept under $11 \mathrm{hL}) . \mathrm{B}=$ green $(\mathrm{observed}$ under all photophases, but mostly under 13 and $14 \mathrm{hL}$ ). 


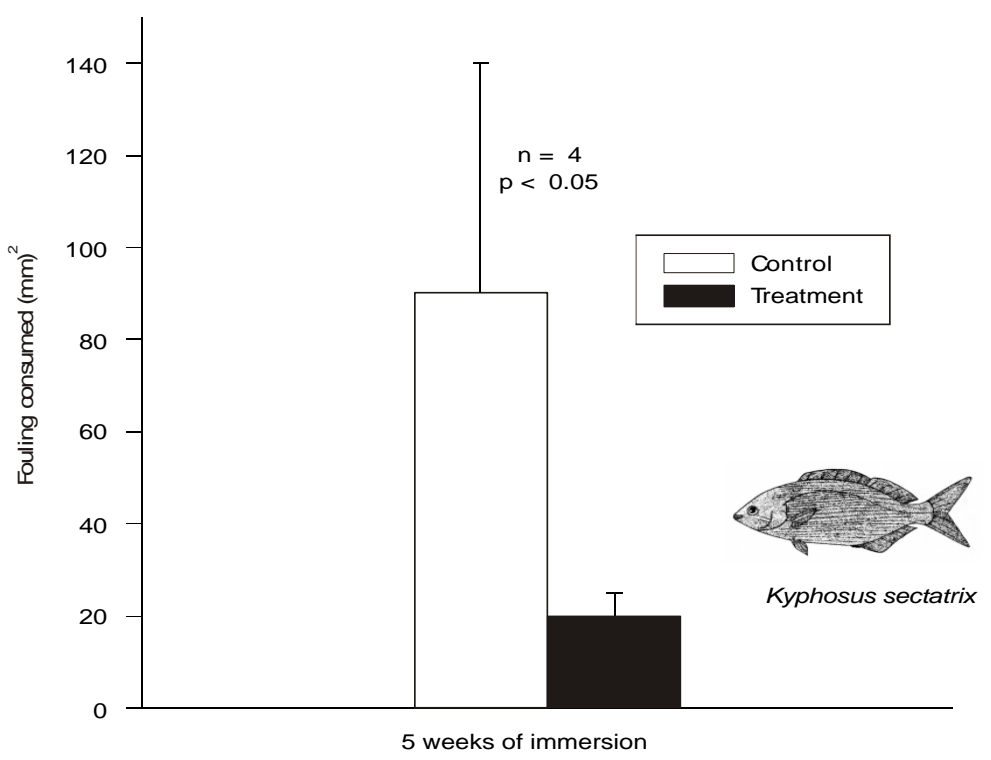

Fig. 5 - Lipid content $(\%)$ in dry body $(\mathrm{X} \pm \mathrm{SEM})$ of Dichelops melacanthus 20-days-old adults, maintained under different photoperiods, feeding on green pods and dry soybean seeds in the laboratory. Means followed by the same letter do not differ significantly (Tukey's test, $\mathrm{p} \leq 0.05 ; \mathrm{n}=20$ ).

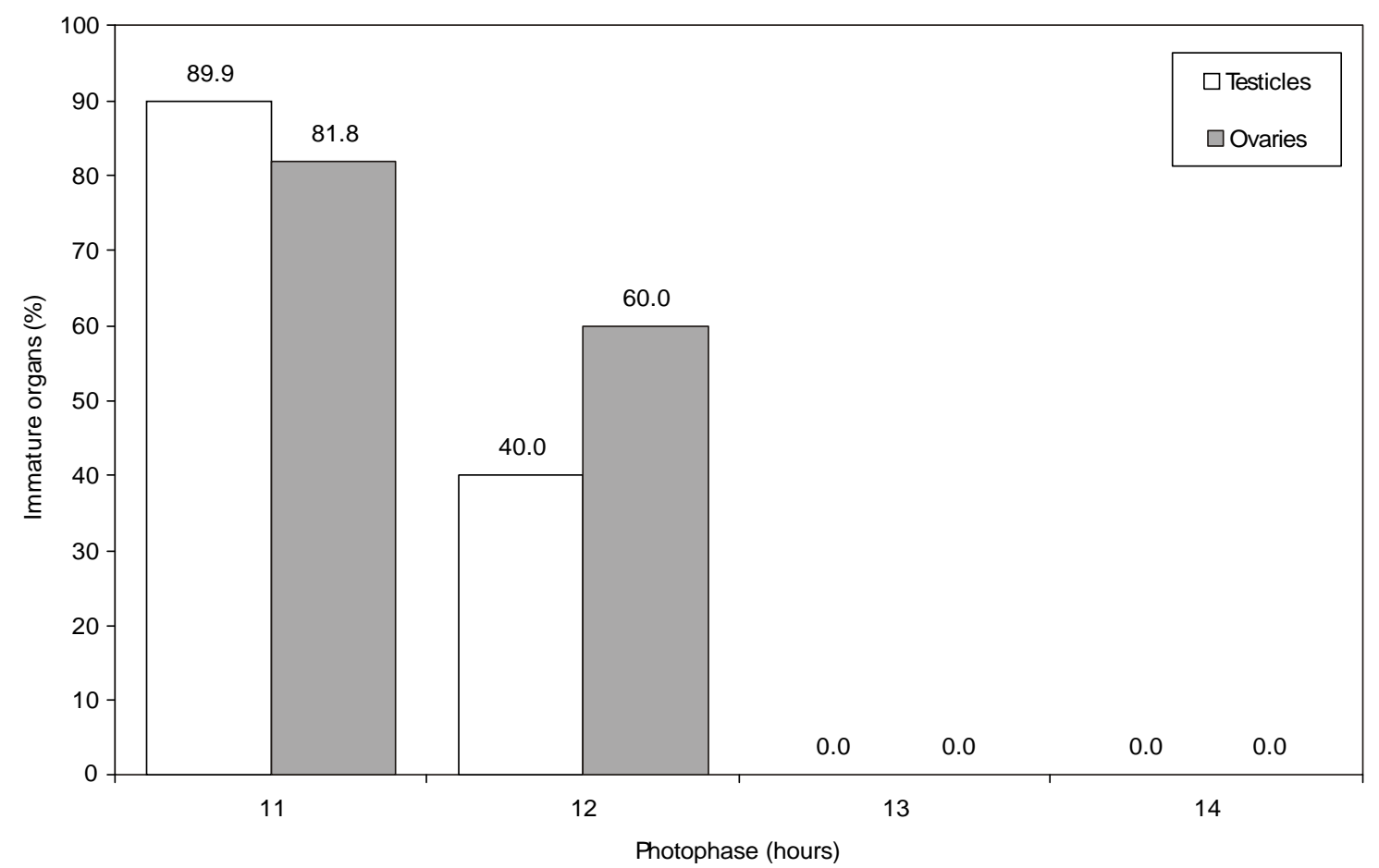

Fig. 6 - Immature reproductive organs (\%) of Dichelops melacanthus under different photoperiods, feeding on green pods and dry soybean seeds in the laboratory $(\mathrm{n}=10)$. 
These laboratory studies indicate that a $14 \mathrm{~h}$ photophase, corresponding to the longer days of summer in northern Paraná State, was the best photoperiodic condition for the development of $D$. melacanthus nymphs. This pentatomid presented reproductive oligopause in the laboratory, induced by 11 and $12 \mathrm{hL}$, and characterized by the occurrence of periodic feeding, even under typical winter photophases. The highest percentage of immature reproductive organs occurred under the shortest photophase. D. melacanthus also showed photoperiod-induced seasonal dimorphism. The abdominal color varied according to both photophase and insect age, and so it was not considered a reliable parameter to evaluate the physiological state or the seasonal form of this pentatomid. The lipid content extracted from $D$. melacanthus adults was higher under shortday rather than long-day conditions.

In conclusion, these data demonstrate that $D$. melacanthus presents different morphs, with different physiological traits, that are driven by photoperiodic conditions. These data coupled with field observations show that the brownish, high-lipid-content, and sexually immature types are found in the soil. This makes plowing and/or elimination of crop residues a potential control strategy for managing this pest.

Acknowledgments - We thank J.R. Salvadori, R.R. Cavichioli, S.M.N. Lázzari, and C.S. Ribeiro-Costa for critical review of the manuscript. This paper was approved for publication by the Editorial Board of Embrapa Soja as manuscript number 21/ 2002.

\section{REFERENCES}

ALBUQUERQUE, G. S., 1989, Ecologia de populações, biologia e estratégias da história de vida de Oebalus poecilus (Dallas, 1851) (Hemiptera: Pentatomidae). Tese de Mestrado, UFRGS, Porto Alegre, 216p.

ALBUQUERQUE, G. S., 1993, Planting time as a tactic to manage the small rice stink bug, Oebalus poecilus (Hemiptera: Pentatomidae) in Rio Grande do Sul, Brazil. Crop Protection, 12: 627-630.

ALI, M. \& EWIESS, M. A., 1977, Photoperiodic and temperature effects on rate of development and diapause in the green stink bug, Nezara viridula L. (Heteroptera: Pentatomidae). Z. Ang. Entomol., 84: 256-264.
HARRIS, V. E., TOOD, J. W. \& MULLINIX, B. G., 1984, Color change as an indicator of adult diapause in the southern green stink bug Nezara viridula. J. Agric. Entomol., 1: 82-91.

HIGUCHI, H., 1994, Photoperiodic induction of diapause hibernation and voltinism in Piezodorus hybneri (Heteroptera: Pentatomidae). Appl. Entomol. Zool., 29: 585-592.

HODEK, I. \& HODKOVÁ, M., 1993, Role of temperature and photoperiod in diapause regulation in Czech populations of Dolycoris baccarum (Heteroptera: Pentatomidae). Eur. J. Entomol., 90: 95-98.

KIRITANI, K., 1963, The change in reproductive system of the southern green stink bug, Nezara viridula and its application to forecasting of the seasonal history. Jap. J. Appl. Entomol. Zool., 7: 327-336.

LEATHER, S. R., WALTERS, K. F. A. \& BALE, J. S., 1993, The ecology of insect overwintering. Cambridge University Press, 255p.

McPHERSON, J. E., 1974, Photoperiodic effects in a southern Illinois population of the Euschistus tristigmus complex (Hemiptera: Pentatomidae). Ann. Entomol. Soc. Am., 67: 943-952.

McPHERSON, J. E., 1975, Effects of developmental photoperiod on adult morphology in Euschistus tristigmus (Say) (Hemiptera: Pentatomidae). Ann. Entomol. Soc. Am., 68: 1107-1110.

MOURÃO, A. P. M. \& PANIZZI, A. R., 2000a, Diapausa e diferentes formas sazonais em Euschistus heros (Fabr.) (Hemiptera: Pentatomidae) no Norte do Paraná. An. Soc. Entomol. Brasil., 29: 205-218.

MOURÃO, A. P. M. \& PANIZZI, A. R., 2000b, Estágios ninfais fotossensíveis à indução da diapausa em Euschistus heros (Fabr.) (Hemiptera: Pentatomidae). An. Soc. Entomol. Brasil., 29: 219-225.

MOURÃO, A. P. M. \& PANIZZI, A. R., 2002, Photophase influence on the reproductive diapause, seasonal morphs, and feeding activity of Euschistus heros (Fabr., 1978) (Hemiptera: Pentatomidae). Braz. J. Biol., 62: 231-238.

NAKAMURA, K. \& NUMATA, H., 1997, Seasonal life cycle of Aelia fieberi (Hemiptera: Pentatomidae) in relation to the phenology of its host plants. Ann. Entomol. Soc. Am., 90: 625-630.

NAKAMURA, K., HODEK, I. \& HODKOVÁ, M., 1996, Recurrent photoperiodic response in Graphosoma lineatum (Heteroptera: Pentatomidae). Eur. J. Entomol., 93: 519-523.

PANIZZI, A. \& CHOCOROSQUI, V., 2000, Os percevejos inimigos. A Granja, 56: 40-42.

SEYMOUR, J. E. \& BOWMAN, G. J., 1994, Russet coloration in Nezara viridula (Hemiptera: Pentatomidae): an unreliable indicator of diapause. Environ. Entomol., 23: 860-863. 